\title{
Engineering Technology Faculty: Attract, Retain, and Motivate Through Total Compensation and Work Experiences
}

\author{
Patricia L. Fox, Stephen P. Hundley \\ Indiana University Purdue University Indianapolis (IUPUI)
}

\begin{abstract}
Since 1977, the Purdue School of Engineering and Technology at Indiana University Purdue University Indianapolis (IUPUI) has conducted and sponsored a national engineering technology faculty salary survey. The Engineering Technology Faculty Salary Survey is conducted annually in cooperation with the Engineering Technology Council (ETC) and the Engineering Technology Division (ETD) of the American Society of Engineering Education (ASEE). The survey has approximately 75 to 90 two- and four-year engineering technology institutions nationwide who participate.
\end{abstract}

The survey results provide engineering technology administrators with a list of participating schools; a summary of minimum, average, and maximum salaries reported separately for twoand four-year schools; a summary of minimum, average, and maximum salaries for all participating schools; raw data listed by code number for all schools; a ten-year salary summary for faculty and administrators; and graphs of the salary data by region and number of faculty.

Reports such as the Engineering Technology Faculty Salary Survey have proven to be a reliable source for developing school compensation plans which seek to attract, retain, and motivate faculty. Some compensation plans not only incorporate guidelines for meritorious increases but also contain suggested plans for new faculty that may include reduced teaching loads, summer support, and/or start-up funds.

This paper will include the 2001-02 Engineering Technology Faculty Salary Survey results. Results of mini-survey conducted in conjunction with the 2001-02 Engineering Technology Faculty Salary Survey concerning new faculty startup funds, new faculty summer support, and faculty teaching assistants will also be reported in this paper. New faculty teaching loads, the teaching of on-line courses, provisions of internal grants, requirements for participating in assessment, peer review, and post tenure review are some of the other questions which were included in the mini-survey. A discussion of how leaders in engineering technology can use total compensation and work experience to enhance their abilities to attract, retain, and motivate their faculty will also be included in this paper.

"Proceedings of the 2002 American Society for Engineering Education Annual Conference \& Exposition Copyright () 2002, American Society for Engineering Education" 


\section{Groundwork}

Before establishing a compensation plan ${ }^{1}$ or goal that will attract, retain and motivate faculty, you need to seek salary comparisons with other institutions, industry, and other similar professional groups.

One of the first steps in establishing a faculty salary base to work from is to conduct a thorough examination of your own engineering technology faculty salaries taking into consideration faculty rank, number of years of experience, number of years in service, educational degrees, and performance. In addition, you need to look at the minimum, maximum, and average salaries for all disciplines and ranks in your institution, school, or program. This information is vital for national and professional comparisons. In addition, it is important to know the demand for engineers in industry and engineering salaries for the discipline. Higher education competes with industry for employees; therefore, you need to know what your competition is paying. Higher education will never be able to compete with industrial salaries for engineers, but we can put together a package that can attract, retain, and motivate our future and current faculty by knowing what our competition offers. Institutions can offer other types of incentives that will attract the right kind of faculty member.

There are two national surveys for engineering technology faculty salaries. The Engineering Workforce Commission (EWC), which is a research and publications branch of the American Association of Engineering Societies (AAES), biennially surveys of universities and colleges employing engineering and engineering technology faculty. The latest edition available is entitled, Salaries of Engineers in Education, 19982. This particular survey contains engineering and engineering technology faculty salaries by years since bachelor degree for all ranks. The report provides salaries for six ranks; full professor, associate professor, assistant professor, instructors, researchers, and other non-teaching staff and administrators. The EWC also provides a survey of the professional income of engineers. The commission surveys companies, organizations, and agencies that employ engineers. The latest version available for this report is entitled, Engineers' Salaries: Special Industry Report, 1999 ${ }^{3}$. As the oldest and largest salary survey of engineers, this report provides statistics on the salaries of approximately 45,000 engineers in industry and government. The report gives salary details by industry sectors, geographic regions, employer size, engineering experience, and supervisory position. These reports can be purchased at a considerable price through AAES.

The Engineering Technology Faculty Salary Survey ${ }^{4}$ is another national engineering technology salary survey, which is conducted annually by the Purdue School of Engineering and Technology in cooperation with the Engineering Technology Division (ETD) and the Engineering Technology Council (ETC) of the American Society of Engineering Education (ASEE). The latest version of the survey is the 2001-02 Engineering Faculty Salary Survey. The benefit of this particular faculty salary survey is that the results are provided free to participating institutions and schools. This survey has been conducted annually since 1976-77. Salary data is provided by rank and administrative level including averages by region and number of faculty.

"Proceedings of the 2002 American Society for Engineering Education Annual Conference \& Exposition Copyright (C) 2002, American Society for Engineering Education” 
Knowing what the current market is for engineers is vital to understanding the demands of the market for engineering technology faculty. To find out what engineering professionals are worth on the open market, you can use the engineering salary surveys provided on the web. Starting salaries for engineers can also be found through Internet sources such as University of Tennessee - Engineering Salary Survey ${ }^{5}$. Industry engineering salary data can also be obtained through Internet web sites like Hitechsalary ${ }^{6}$, National Engineering Search ${ }^{7}$, or Wageweb Engineering Salary Data $^{8}$, to name just a few. Engineering periodicals, such as Machine Design ${ }^{9}$, also regularly publish salary surveys in their magazines. There are numerous sources found on the web to give information about the current market and salaries of the types of engineers you are seeking to hire at your institution.

Other considerations for developing salary standards within an engineering technology institution and/or school, is to research the current and future demands for engineers. Information concerning future needs for engineers and how many are currently in the pipeline can be found in publications like the Engineers Newsletter ${ }^{10}$, which is published by AAES. For example, the newsletter provides analysis of how declining or increasing numbers of engineering graduates compare to the national trends in degrees awarded or how many engineers will be needed 10 years from now. The newsletter is produced four times per year and reports on various topics concerning engineers. An annual subscription costs approximately $\$ 100$ per year.

Results of Past Surveys

For the past twenty-five years, the Purdue School of Engineering and Technology at IUPUI has conducted the national Engineering Technology Faculty Salary Survey. This survey is conducted in cooperation with the Engineering Technology Division (ETD) and the Engineering Technology Council (ETC) of the American Society for Engineering Education. The survey results provide participants with a list of participating institutions, a summary of minimum, maximum, and average salary for administrators and faculty in each rank for two and four year institutions, and for a combination of all schools, 10 year salary summary, a list of institutions by region, and average salaries for administrators and faculty by region and number of faculty.

Institutional identities for raw data provided in the results are protected by a school identification code. All participants are provided with the results free of charge.

It's important to know the history of national trends in looking at your overall compensation plan. Table 1 illustrates the average salary for administrators by rank for all participating schools from 1977-78 through 2001-02, a total of twenty-five years. One year, 1993-94, is missing from the salary data because the survey was not conducted in that year. Administrator average salaries in Table 1 are for a twelve-month period.

Table 1. ET Administrator Average Salary by Rank - All Participating Schools

\begin{tabular}{|c|c|c|c|c|}
\hline & Dean/ & Associate & Assistant & Department \\
\hline Year & Director & Dean/Director & Dean/Director & Head/Chair \\
\hline $2001-02$ & 101,702 & 96,359 & 78,513 & 82,794 \\
\hline $2000-01$ & 103,698 & 106,044 & 72,860 & 79,194 \\
\hline $1999-00$ & 89,366 & 95,013 & 64,724 & 70,637 \\
\hline
\end{tabular}

"Proceedings of the 2002 American Society for Engineering Education Annual Conference \& Exposition Copyright (C) 2002, American Society for Engineering Education” 


\begin{tabular}{|l|c|c|r|r|}
$\begin{array}{l}\text { (Continued } \\
\text { Table 1.) } \\
\text { Year }\end{array}$ & $\begin{array}{l}\text { Dean/ } \\
\text { Director }\end{array}$ & $\begin{array}{l}\text { Associate } \\
\text { Dean/Director }\end{array}$ & $\begin{array}{l}\text { Assistant } \\
\text { Dean/Director }\end{array}$ & $\begin{array}{l}\text { Department } \\
\text { Head/Chair }\end{array}$ \\
\hline $1998-99$ & 101,386 & 100,236 & 65,034 & 76,921 \\
\hline $1997-98$ & 92,515 & 89,899 & 64,628 & 73,051 \\
\hline $1996-97$ & 78,438 & 79,864 & 60,612 & 64,854 \\
\hline $1995-96$ & 94,455 & 91,505 & 69,277 & 69,540 \\
\hline $1994-95$ & 88,993 & 88,390 & 62,372 & 76,176 \\
\hline $1993-94$ & n/a & n/a & n/a & n/a \\
\hline $1992-93$ & 81,846 & 72,790 & 54,102 & 61,694 \\
\hline $1991-92$ & 76,646 & 76,294 & 52,983 & 61,418 \\
\hline $1990-91$ & 74,955 & 60,622 & 44,880 & 55,014 \\
\hline $1989-90$ & 70,370 & 67,704 & 54,978 & 42,563 \\
\hline $1988-89$ & 64,470 & 54,174 & 54,356 & 42,678 \\
\hline $1987-88$ & 61,751 & 55,424 & 43,834 & 49,676 \\
\hline $1986-97$ & 58,248 & 55,043 & 43,105 & 47,210 \\
\hline $1985-86$ & 56,620 & 50,368 & 42,226 & 45,804 \\
\hline $1984-85$ & 53,605 & 47,405 & 39,638 & 41,553 \\
\hline $1983-84$ & 46,523 & 41,002 & 34,325 & 39,555 \\
\hline $1982-83$ & 44,213 & 40,736 & 35,173 & 38,514 \\
\hline $1981-82$ & 41,427 & 39,364 & 27,725 & 35,664 \\
\hline $1980-81$ & 37,858 & 31,592 & 31,738 & 31,073 \\
\hline $1979-80$ & 34,838 & 28,710 & 28,107 & 27,803 \\
\hline $1978-79$ & 32,914 & 30,351 & 26,373 & 25,164 \\
\hline $1977-78$ & 33,585 & 29,279 & 27,655 & 25,789 \\
\hline & & & & \\
\hline
\end{tabular}

In 1977 , the average salary for Dean/Director for all participating schools was $\$ 33,585$. Today, the average salary for the same rank is $\$ 101,702$, a difference of $\$ 68,117$ or an increase of $303 \%$ over the twenty-five year period. In comparison, salaries increased $329 \%$ for Associate Dean/Directors, 284\% for Assistant Deans/Directors, and 321\% for Department Head/Chairs for the same period of time. Table 2 shows the salary difference and percent increase for the Engineering Technology Administrators for the twenty-five year period.

Table 2. Average Salary, \$ Difference, and \% Increase, for ET Administrators

\begin{tabular}{|c|c|c|c|c|}
\hline & Dean/ & Associate & Assistant & Department \\
\hline Year & Director & Dean/Director & Dean/Director & Head/Chair \\
\hline $2001-02$ & 101,702 & 96,359 & 78,513 & 82,794 \\
\hline $1977-78$ & 33,585 & 29,279 & 27,655 & 25,789 \\
\hline \$ Difference & 68,117 & 67,080 & 50,858 & 57,005 \\
\hline \% Increase & $303 \%$ & $329 \%$ & $284 \%$ & $321 \%$ \\
\hline
\end{tabular}

Table 3 is the average salary data for faculty of all ranks for all participating schools. The faculty salaries are reported for 9/10-month salaries.

"Proceedings of the 2002 American Society for Engineering Education Annual Conference \& Exposition Copyright (C) 2002, American Society for Engineering Education” 
Table 3. ET Faculty Average Salary by Rank - All Participating Schools

\begin{tabular}{|l|r|r|r|r|}
\hline & & Associate & Assistant & \\
\hline Year & Professor & Professor & Professor & Lecturer \\
\hline $2001-02$ & 70,736 & 62,000 & 51,736 & 45,776 \\
\hline $2000-01$ & 69,438 & 58,081 & 50,762 & 42,945 \\
\hline $1999-00$ & 63,621 & 55,187 & 45,452 & 38,426 \\
\hline $1998-99$ & 63,905 & 54,610 & 46,840 & 41,611 \\
\hline $1997-98$ & 62,138 & 52,320 & 44,905 & 36,616 \\
\hline $1996-97$ & 60,259 & 51,092 & 42,998 & 44,166 \\
\hline $1995-96$ & 57,981 & 49,078 & 43,127 & 36,398 \\
\hline $1994-95$ & 53,320 & 48,965 & 41,753 & 35,068 \\
\hline $1993-94$ & $\mathrm{n} / \mathrm{a}$ & $\mathrm{n} / \mathrm{a}$ & $\mathrm{n} / \mathrm{a}$ & $\mathrm{n} / \mathrm{a}$ \\
\hline $1992-93$ & 51,467 & 44,783 & 39,512 & 32,686 \\
\hline $1991-92$ & 50,216 & 43,251 & 37,741 & 32,215 \\
\hline $1990-91$ & 49,336 & 42,808 & 36,713 & 32,380 \\
\hline $1989-90$ & 46,372 & 39,427 & 34,905 & 31,715 \\
\hline $1988-89$ & 42,777 & 37,663 & 31,887 & 27,595 \\
\hline $1987-88$ & 40,285 & 35,281 & 30,815 & 26,015 \\
\hline $1986-97$ & 39,712 & 34,399 & 29,090 & 25,186 \\
\hline $1985-86$ & 37,234 & 32,664 & 27,831 & 24,115 \\
\hline $1984-85$ & 35,222 & 30,358 & 26,262 & 22,642 \\
\hline $1983-84$ & 33,209 & 28,539 & 24,687 & 21,265 \\
\hline $1982-83$ & 31,824 & 26,987 & 23,440 & 20,140 \\
\hline $1981-82$ & 30,175 & 25,888 & 22,257 & 18,628 \\
\hline $1980-81$ & 26,926 & 22,663 & 19,803 & 17,132 \\
\hline $1979-80$ & 24,376 & 20,671 & 17,892 & 15,657 \\
\hline $1978-79$ & 23,517 & 19,575 & 17,488 & 14,542 \\
\hline $1977-78$ & 22,012 & 18,947 & 16,534 & 14,514 \\
\hline
\end{tabular}

A similar comparison made for faculty ranks indicates an increase of 321\% for Professors, 327\% for Associate Professors, 313\% for Assistant Professors, and 315\% for Lecturers over the twenty-five year period. Table 4 shows the salary difference and percent increase for the Engineering Technology Faculty for the twenty-five year period.

Table 4. Average Salary, \$ Difference, and \% Increase, for ET Faculty

\begin{tabular}{|c|c|c|c|c|}
\hline & & Associate & Assistant & \\
\hline Year & Professor & Professor & Professor & Lecturer \\
\hline $2001-02$ & 70,736 & 62,000 & 51,736 & 45,776 \\
\hline $1977-78$ & 22,012 & 18,947 & 16,534 & 14,514 \\
\hline \$ Difference & 48,724 & 43,053 & 35,202 & 31,262 \\
\hline$\%$ Increase & $321 \%$ & $327 \%$ & $313 \%$ & $315 \%$ \\
\hline
\end{tabular}

The Associate Dean/Director rank gained the most increase over the period of time, followed by ranks of Associate Professor, Professor, Department Head/Chair, Lecturer, Assistant Professor, Dean, and Assistant Dean. 
The 2001-02 Engineering Technology Faculty Salary Survey ${ }^{11}$ was conducted during fall 2001. Results of the survey will be disseminated in March of 2002 to participants. Of the 80 participating institution, 13 are two-year schools and 67 are four-year schools. Average salaries were calculated using a weighted average based on the number of faculty in each rank per institution. Tables 5 and 6 show the two-year participating school's minimum, maximum, and average by rank for administrators and faculty.

Table 5. 2001-02 Two-year Participating Schools - ET Administrators

\begin{tabular}{|l|c|r|r|r|}
\hline 12 Month-Term & Number & \$ Minimum & \$ Maximum & \multicolumn{1}{|c|}{$\$$ Average } \\
\hline Dean/Director & 15 & 55,000 & 109,762 & 73,665 \\
\hline Associate Dean/Director & 1 & 65,004 & 65,004 & 65,004 \\
\hline Assistant Dean/Director & 3 & 48,075 & 72,114 & 57,363 \\
\hline Department Head/Chair & 13 & 45,000 & 66,242 & 56,601 \\
\hline
\end{tabular}

Table 6. 2001-02 Two-year Participating Schools - ET Faculty

\begin{tabular}{|l|c|r|r|r|}
\hline 9/10 Month-Term & Number & \$ Minimum & $\$$ Maximum & $\$$ Average \\
\hline Professor & 18 & 42,000 & 87,000 & 67,860 \\
\hline Associate Professor & 30 & 33,000 & 75,500 & 66,379 \\
\hline Assistant Professor & 19 & 28,000 & 65,000 & 51,365 \\
\hline Lecturer & 152 & 33,000 & 65,000 & 47,597 \\
\hline
\end{tabular}

Only 13 two-year schools participated in the 2001-02 survey. Unfortunately, the number of participating schools for two-year programs was too low for the information to be very meaningful.

Table 7 and 8 illustrate the same information for four-year participating schools. Sixty-seven four-year schools participated in the 2001-02 survey. Tables 9 and 10 show the same information for all participating schools.

Table 7. 2001-02 Four-year Participating Schools - ET Administrators

\begin{tabular}{|l|c|r|r|r|}
\hline 12 Month-Term & Number & $\$$ Minimum & $\$$ Maximum & \$ Average \\
\hline Dean/Director & 50 & 61,000 & 228,000 & 110,113 \\
\hline Associate Dean/Director & 27 & 50,000 & 201,600 & 97,520 \\
\hline Assistant Dean/Director & 20 & 41,760 & 136,509 & 81,686 \\
\hline Department Head/Chair & 139 & 46,000 & 210,092 & 85,243 \\
\hline
\end{tabular}

Table 8. 2001-02 Four-year Participating Schools - ET Faculty

\begin{tabular}{|l|c|c|c|c|}
\hline 9/10 Month-Term & Number & \$ Minimum & $\$$ Maximum & \$ Average \\
\hline Professor & 277 & 46,194 & 132,000 & 70,923 \\
\hline Associate Professor & 392 & 39,969 & 91,926 & 61,665 \\
\hline Assistant Professor & 423 & 34,407 & 72,000 & 51,752 \\
\hline Lecturer & 189 & 29,260 & 69,642 & 44,312 \\
\hline
\end{tabular}

"Proceedings of the 2002 American Society for Engineering Education Annual Conference \& Exposition Copyright (C) 2002, American Society for Engineering Education” 
Table 9. 2001-02 All Participating Schools - ET Administrators

\begin{tabular}{|l|c|c|c|c|}
\hline 12 Month-Term & Number & \$ Minimum & \$ Maximum & $\$$ Average \\
\hline Dean/Director & 65 & 55,000 & 228,000 & 101,702 \\
\hline Associate Dean/Director & 28 & 50,000 & 201,600 & 96,359 \\
\hline Assistant Dean/Director & 23 & 41,760 & 136,509 & 78,513 \\
\hline Department Head/Chair & 152 & 45,000 & 210,092 & 82,794 \\
\hline
\end{tabular}

Table 10. 2001-02 All Participating Schools - ET Faculty

\begin{tabular}{|l|c|r|r|r|}
\hline 9/10 Month-Term & Number & \$ Minimum & \$ Maximum & \$ Average \\
\hline Professor & 295 & 42,000 & 132,000 & 70,736 \\
\hline Associate Professor & 422 & 33,000 & 91,926 & 62,000 \\
\hline Assistant Professor & 442 & 28,000 & 72,000 & 51,736 \\
\hline Lecturer & 341 & 29,260 & 69,642 & 45,776 \\
\hline
\end{tabular}

The salary results from this survey have been used for years as a basis for national salary comparisons. Annual results should be viewed with caution in making comparisons due to various anomalies. For example, if some administrative maximum seems very high, it may be because the engineering technology programs are based in an engineering school. It is not a secret that engineering deans are paid higher than engineering technology deans. If a minimum in a particular year appears to be very low, it may be caused by the inclusion of a very small twoyear school with perhaps one engineering technology program. In addition, while the questionnaire for this survey attempts to be straight forward, varying interpretations of instructions and definitions are possible. Even with the cautions of interpreting the data, this survey has proven to be a successful tool of engineering technology administrators and continues to provide valuable data for the engineering technology education community.

Response to Faculty Work Experiences Questionnaire

Included in this year's Engineering Technology Faculty Salary Survey was a questionnaire specifically designed to find out about faculty issues as they relate to work experiences associated with retention and hiring factors in engineering technology. Seventy-three questionnaires were returned with the following responses to the questions.

1. Do you provide any start-up seed money for new (tenure-track) faculty:

\begin{tabular}{|r|r|r|r|}
\hline & Yes & No & Not Answered \\
\hline Research/Creative Activities? & 28 & 38 & 7 \\
\hline Course development? & 30 & 35 & 8 \\
\hline
\end{tabular}

2. Do you provide summer support for new faculty? Yes or No

\begin{tabular}{|r|r|r|}
\hline Yes & No & Not Answered \\
\hline 38 & 28 & 7 \\
\hline
\end{tabular}

"Proceedings of the 2002 American Society for Engineering Education Annual Conference \& Exposition Copyright @ 2002, American Society for Engineering Education" 
3. Do you provide new faculty with:

\begin{tabular}{|r|r|r|r|}
\hline & Yes & No & Not Answered \\
\hline Research assistant support? & 10 & 56 & 7 \\
\hline Teaching assistant support? & 24 & 42 & 7 \\
\hline
\end{tabular}

4. What are new faculty teaching loads?

a. Answer for Semester system

\begin{tabular}{|r|r|}
\hline One or two courses per semester? & 12 \\
\hline Three or four courses per semester? & 42 \\
\hline More than four courses per semester? & 9 \\
\hline
\end{tabular}

b. Answer for Quarter system

\begin{tabular}{|r|r|}
\hline One or two courses per quarter? & 6 \\
\hline Three or four courses per quarter? & 0 \\
\hline More than four courses per quarter? & 4 \\
\hline
\end{tabular}

5. Do you require faculty (tenure-track or tenured) to teach online courses:

\begin{tabular}{|r|r|r|r|}
\hline & Yes & No & Not Answered \\
\hline All courses taught online? & 2 & 56 & 15 \\
\hline Some courses taught online? & 14 & 46 & 13 \\
\hline No courses taught online? & 24 & 34 & 15 \\
\hline
\end{tabular}

6. Do you provide incentives or recognition awards for faculty (tenure-track or tenured) in any of these areas:

\begin{tabular}{|r|r|r|r|}
\hline & Yes & No & Not Answered \\
\hline Teaching? & 56 & 8 & 9 \\
\hline Research/Creative Activities? & 47 & 14 & 12 \\
\hline Service? & 43 & 18 & 12 \\
\hline
\end{tabular}

7. Do you provide internal grant competitions for faculty (tenure-track or tenured) in any of these areas:

\begin{tabular}{|r|r|r|r|}
\hline & Yes & No & Not Answered \\
\hline Teaching? & 42 & 23 & 8 \\
\hline Research/Creative Activities? & 50 & 15 & 8 \\
\hline Service? & 20 & 42 & 11 \\
\hline
\end{tabular}

8. Do you require faculty (tenure-track and tenured) to participate in assessment activities?

\begin{tabular}{|r|r|r|}
\hline Yes & No & Not Answered \\
\hline 60 & 4 & 9 \\
\hline
\end{tabular}

"Proceedings of the 2002 American Society for Engineering Education Annual Conference \& Exposition Copyright () 2002, American Society for Engineering Education” 
9. Do you provide peer-review of teaching for:

\begin{tabular}{|r|r|r|r|}
\hline & Yes & No & Not Answered \\
\hline Tenure-track faculty? & 38 & 28 & 7 \\
\hline Tenured faculty? & 26 & 40 & 7 \\
\hline Adjunct/part-time faculty? & 31 & 34 & 8 \\
\hline
\end{tabular}

10. Do you provide post-tenure review for tenured faculty?

\begin{tabular}{|r|r|r|}
\hline Yes & No & Not Answered \\
\hline 38 & 26 & 9 \\
\hline
\end{tabular}

From the data collected, it appears that around $40 \%$ of engineering technology schools provide funding for both course development and research/creative activities with slightly more funding going towards course development. This is not surprising, since a majority of engineering technology faculty focus their work more in the domain of teaching excellence, with regards to promotion and tenure, than their engineering counterparts (who are, perhaps, more researchoriented for promotion and tenure purposes). A majority of engineering technology schools, $52 \%$, provide summer support for new faculty. Only a small number, $25 \%$, provide research assistant support and 33\% provide teaching assistant support.

Teaching loads range from one or two courses to more than four courses per semester or quarter. Fifty eight percent report that their faculty teaches three to four courses per semester. Combined semester and quarter, less than $18 \%$ teach more than four courses. In response to whether faculty are required or encouraged to teach on-line courses, the response was less than $3 \%$ required faculty to teach on-line.

Schools responded positively to providing incentives or recognitions to faculty for work. Seventy-eight percent provided incentives and recognitions for teaching, $64 \%$ for research/creative activities, and 59\% for service. Schools also provide internal grants for teaching, research/creative activity, and service, at 52\%, 36\%, and $42 \%$, respectively.

Regarding peer-review, 52\% percent of the schools provide peer-review of teaching for tenure track faculty. Only $36 \%$ provide peer-review for tenured faculty and $42 \%$ provide peer review for adjunct or part-time faculty. A majority, $52 \%$ of the schools, responded that they provide post tenure review for faculty, a hot topic in higher education.

Comparisons can be made on several questions in the survey about faculty issues as they relate to some retention and hiring factors in engineering technology with results in the 1999Engineering Technology Trends and Development Survey ${ }^{12}$. The trends and development survey was conducted for the Engineering Technology Division (ETD) and the Two Year College Division (TCD) of ASEE. This particular survey has been conducted since 1977, every four years, to track trends and developments in engineering technology education. A total of 104 institutions responded to the 129 questions in the 1999 survey.

In the 1999 survey, $69 \%$ of the four-year schools reported that the average teaching load for full time faculty was 10.79 credit hours per semester, $31 \%$ reported an average of 13.79 credit hours

"Proceedings of the 2002 American Society for Engineering Education Annual Conference \& Exposition Copyright () 2002, American Society for Engineering Education” 
per semester. Two-year schools reported that their faculty taught an average of 14.46 credit hours per semester. Comparisons with the current survey indicated a similarity with regards to teaching loads, $58 \%$ percent reported that their faculty taught three to four courses per semester or the equivalent 9 to 12 credit hours. In making comparisons, please note that only 73 schools responded to this year's survey of which a vast majority (64) were four-year schools.

A related question concerning distance learning/education, number 5 on this year's survey, was asked on the 1999 trends and development survey. Four-year schools answered that 54\% offered distance learning/education courses. In general, schools do not require faculty to teach on-line courses as indicated in responses to survey question number 5; however, distance learning/education is important and is being conducted in engineering technology schools.

Data from the 1999 trends and development survey relevant to the topic at hand, using compensation and work experience to attract, retain, and motivate faculty, indicates that $45 \%$ of the four-year engineering technology schools and $49 \%$ of the two-year schools showed salary was a major hiring problem. This is a good reason to consider looking at other noncompensation methods to attract and retain faculty to engineering technology.

\section{Conclusion}

While higher education may never be able to offer cash compensation at the same levels as private-sector counterparts, there is the potential to attract, retain, and motivate top talent in the form of creating a package that includes both compensation and work experiences that seek to meet both the individual candidate's needs while simultaneously meeting institutional priorities for teaching, research, and service.

Administrators can play a key role in selling their institution to the right candidate they can assist by retaining faculty that would be potentially lured away and by emphasizing some of the noncash work experience aspects of the job, including: autonomy over one's time; acade mic freedom (relative to the pursuit of research interests); teaching environments that are conducive to innovation and flexibility (such as the option of teaching online courses); professional development, internal grant opportunities; reward, recognition, and incentive programs; and support for teaching and research effectiveness (through the use of release-time, appropriate teaching loads, and/or graduate teaching- and research-assistant support).

By using data contained in salary surveys, such as the ones discussed in this paper, to effectively plan an approach to cash compensation, coupled with an ongoing assessment of the totality of the broader work environment, administrators can strike an appropriate chord in seeking to more effectively attract, retain, and motivate their faculty.

Bibliography

1. Fox, P.L., Hundley, S.P., and Yurtseven, H. O., "Developing a Compensation Plan for Increasing Engineering and Technology Faculty Salaries," 2001 ASEE Conference Proceedings.

"Proceedings of the 2002 American Society for Engineering Education Annual Conference \& Exposition Copyright (C) 2002, American Society for Engineering Education” 
2. Engineering Workforce Commission of the American Society of Engineering Societies, Inc., "Salaries of Engineers in Education, 1998"

3. Engineering Workforce Commission of the American Society of Engineering Societies, Inc., "Engineers' Salaries: Special Industry Report, 1999"

4. Fox, P.L. and Yurtseven, H.O., "2000-01 Engineering Technology Faculty Salary Survey,” Purdue School of Engineering and Technology, IUPUI. 2001.

5. University of Tennessee - Engineering Salary Survey, http://www.engr.utk.edu/org/studorg/ans/salary.html

6. Engineering Salary Survey, http://hitechsalary.com.

7. National Engineering Search, http://www.nesnet.com/.

8. Wageweb Engineering Salary Data, http://www.wageweb.com/eng1.htm.

9. Machine Design, http://www.machinedesign.com/.

10. Engineering Workforce Commission of the American Society of Engineering Societies, Inc. "Engineers Newsletter."

11. Fox, P.L. and Yurtseven, H.O., "2001-02 Engineering Technology Faculty Salary Survey,” Purdue School of Engineering and Technology, IUPUI. Feb/March 2002.

12. P.L. Fox, "1999Engineering Technology Trends and Development Survey," Purdue School of Engineering and Technology, IUPUI. June 2000.

\section{PATRICIA L. FOX}

Patricia L. Fox is the Assistant Dean for Administration and Finance and Assistant Professor of Organizational Leadership and Supervision in the Purdue School of Engineering and Technology at Indiana University-Purdue University Indianapolis (IUPUI). Pat is the chief financial officer of the school and has been author and co-author of the national Engineering Technology Faculty Salary Survey since 1980. In addition to her administrative duties, Pat teaches in the Department of Organizational Leadership and Supervision. She holds a MBA from Butler University.

\section{STEPHEN P. HUNDLEY}

Stephen P. Hundley is Assistant Professor of Organizational Leadership and Supervision in the Purdue School of Engineering and Technology at Indiana University-Purdue University Indianapolis (IUPUI), where he teaches human resources management, labor relations, and strategic compensation. Prior to his appointment at IUPUI, Stephen worked in training, human resources, and management consulting. He regularly speaks on higher education and human resources issues to a variety of audiences. Stephen holds a Ph.D. from American University, and is certified by the Society for Human Resource Management as a Senior Professional in Human Resources. 